\title{
Inquietudes da crítica literária militante de Antonio Candido*
}

Rodrigo Martins Ramassote

Entre os anos de 1943 e 1947, Antonio Candido atuou como crítico literário militante na grande imprensa paulista, assinando os rodapés da coluna "Notas de crítica" nos jornais Folha de S. Paulo (de janeiro de 1943 a janeiro de 1945) e Diário de S. Paulo (de setembro de 1945 a fevereiro de 1947). No total, foram publicados 162 escritos, dos quais oitenta foram recolhidos em livros (Brigada ligeira, de 1945, e Observador literário, de 1959), revistas (Literatura e Sociedade, Remate de Males, Inimigo Rumor, entre outras), ou reunida em um volume organizado por Vinicios Dantas (cf. 2002b).

Como se sabe, com o prestígio amealhado pela participação na seção de crítica literária da revista Clima - quando ainda era estudante no Curso de Ciências Sociais (1939-1941) da Faculdade de Filosofia Ciências e Letras da Universidade de São Paulo (FFCL-USP) -, Candido viabilizou seu ingresso na imprensa diária de São Paulo². Indicado por Lourival Gomes Machado, também formado em Ciências Sociais e colaborador da seção de artes plásticas, e sob o aval de Hermínio Sacchetta ${ }^{3}$ (diretor de redação), assumiu a condição de crítico titular no jornal Folha da Manhã, com a obrigação de "fornecer semanalmente, sobre livros do momento, um comentário que ocupava toda a parte inferior de uma das páginas internas, o 'rodapé' (antigamente, 'folhetim'), subordinado a uma rubrica geral invariável, que dava nome à secção e vinha impressa acima do título de cada artigo" (Candido, 1992a, p. 10).
* Agradeço a Luiz Carlos Jackson pelo convite e aos integrantes do Projeto Temático da Fapesp "Formação do campo intelectual e da indústria cultural no Brasil contemporâneo" pela leitura crítica, estímulos e sugestôes a uma primeira versão deste texto.

1. Editada entre maio de 1941 e novembro de 1944 , a revista Clima perdurou por dezesseis ediçōes. À frente da seção de crítica literária, Candido assinou 28 contribuiçōes, distribuídas entre artigos, resenhas e notas (algumas delas com pseudônimos). Sobre Clima, ver Pontes (1998).

2. Cf. Pontes (1998, p. 112).

3. Ex-militante do Partido Comunista Brasileiro (PCB) - com o qual rompe por divergências ideológicas em 1939 - e então dirigente da organização trotskista Partido Socialista Revolucionário (PSR), o jornalista paulista Hermínio Sachetta (1909-1982) iniciou sua carreira como revisor no Correio Paulistano. Em novembro de 1937, assumiu o 
cargo de diretor de redação na Folha da Manbã.

4. Cf. Bolle (1979), Lafetá (2000), Candido (1988, 2000a), Johnson (1995) e Pontes (2001).
O exame das posturas e alianças políticas, ambições intelectuais, pressupostos doutrinários, preferências literárias, autores privilegiados e conceitos analíticos incrustados nesse material depende da consideração de quatro frentes correlatas de pesquisa. Em primeiro lugar, os contornos mais gerais do contexto social e clima político-ideológico desses anos. Período de intensa agitação política, os anos de 1943 a 1945 marcam, no plano interno, o declínio do Estado Novo (e seus corolários: os primeiros movimentos contestatórios, a reorganização da vida política, o abrandamento da censura etc.) e, no externo, o desfecho da Segunda Guerra Mundial. Em segundo lugar, a alternância vivida por Candido entre a atividade de crítica literária e a profissionalização acadêmica na área da sociologia. A inserção na FFCL-USP - como professor-assistente da Cadeira de Sociologia II (sob a direção de Fernando de Azevedo) e dando prosseguimento às etapas da carreira acadêmica (ao ingressar no curso de Especialização) - repercutiu profundamente na perspectiva analítica adotada por ele nos rodapés. Em seguida, a militância política em pequenos grupos de esquerda. Aderindo à luta contra a ditadura varguista, Candido assume posiçōes políticas e intelectuais combativas, participando de agrupamentos de oposição na esteira do processo de retomada da democracia. Por fim, a apreensão, por parte do jovem crítico, do movimento e vida literária do início da década. Assinalado pelo convívio entre os remanescentes do modernismo e as novas tendências e autores que despontavam.

Conforme afirma a bibliografia sobre o assunto $^{4}$, a década de 1940 prolonga e acentua as transformações de ordem estrutural e ideológica do decênio anterior: expansão do mercado editorial e do sistema de ensino, ampliação da grande imprensa e aumento do número de periódicos, acirramento da polarização de ideários políticos e religiosos, entre outras. Mas, no plano literário, caracteriza uma época de transição, em que veteranos consagrados das primeiras gerações modernistas e jovens estreantes dividem a cena literária. Às publicações tardias de escritores associados ao modernismo ou à geração de 1930 (Mário de Andrade, Oswald de Andrade, Jorge Amado, José Lins do Rego, Carlos Drummond de Andrade, Murilo Mendes, Érico Veríssimo etc.) se juntam as primeiras obras de Clarice Lispector, João Cabral de Mello Neto, Fernando Sabino, Geir Campos, Lêdo Ivo, entre outros.

Dos 92 rodapés redigidos durante o período em que atuou na Folha da Manhã, Candido selecionou e refundiu dezoito para compor os ensaios do seu livro de estreia, Brigada ligeira, publicado em fins do primeiro semestre de 1945 . Neste artigo pretendo rastrear as principais discussóes que mar- 
caram a produção intelectual de Candido nessa primeira fase, para então finalizar com comentários sobre os critérios que presidiram a reunião e a organização dos ensaios do livro.

\section{O método crítico de Antonio Candido}

Conforme prescrevia a tradição, em seu artigo de estreia na Folha da Ma$n h a \tilde{a}$ - intitulado "Ouverture" - Candido delineia o programa de trabalho a ser seguido, destacando os fundamentos e a afinidade de seu método crítico com o contexto histórico abrangente. Recusando o impressionismo como finalidade última do julgamento crítico, admite, contudo, a sua validade como "prolegômeno a toda atividade crítica" (Candido, [1943]* 2002c, p. 25). Por outro lado, a chamada "crítica científica", pautada pelo ânimo de superar as "condições personalíssimas" que constituem a base da avaliação em nome de "fórmulas aplicáveis 'objetivamente", consiste, no fundo, numa quimera: "pedantismos criados pela pretensão dos homens de letras" (Idem, p. 24). Deflagrada pelas impressóes pessoais, a qualidade e a penetração da leitura ainda subordinada à "aventura do espírito" será superada, numa segunda etapa, pelo esforço de "integrar a significação de uma obra no seu momento cultural" (Idem, p. 25).

De acordo com os principais estudos sobre a crítica literária no Brasil, a década de 1940 e a seguinte constituem o momento de apogeu do rodapé, em cujas sessões atuavam representantes já veteranos da "crítica modernista" (Tristão de Athayde, Mário de Andrade, Sergio Buarque de Holanda, Sergio Milliet, Álvaro Lins, para citar os mais conhecidos), ao lado de jovens recém-formados pelas faculdades de filosofia que surgiam pelo país. Nas palavras de Süssekind,

Os anos 1940 e 1950 estão marcados no Brasil pelo triunfo da "crítica de rodapé". O que significa dizer: por uma crítica ligada fundamentalmente à não especialização da maior parte dos que se dedicam a ela, na sua quase totalidade "bacharéis"; ao meio em que é exercida, isto é, o jornal - o que lhe traz, quando nada, três características formais bem nítidas: a oscilação entre crônica e noticiário puro e simples, o cultivo da eloquência, já que se tratava de convencer rápido leitores e antagonistas, e a adaptação às exigências (entretenimento, redundância e leitura fácil) e ao ritmo industrial da imprensa; a uma publicidade, uma difusão bastante grande (o que explica, de um lado, a quantidade de polêmicas e, de outro, o fato de alguns críticos se julgarem verdadeiros "diretores de consciência” de seu público,
* A data entre colchetes refer-se à edição original da obra. Ela é indicada na primeira vez que a obra é citada. Nas demais, indicase somente a edição utilizada pelo autor.

5. A expressão foi cunhada por Wilson Martins (1999). 
como costumava dizer Álvaro Lins; e, por fim, a um diálogo estreito com o mercado, com o movimento editorial seu contemporâneo (Süssekind, 2002, p. 17).

Dada a centralidade da literatura e da imprensa diária na vida intelectual do período, o exercício regular de uma coluna ou rodapé de crítica literária era bastante cobiçado, atraindo o interesse e atiçando as pretensões de seus possíveis postulantes. Emitindo juízos, aclamando ou condenando estreias e lançamentos literários, estabelecendo critérios e formando cânones, o estatuto adquirido e o papel exercido pelo crítico conferiam influência e autoridade para arbitrar legitimamente sobre a dinâmica da vida cultural.

Com a criação da FFCL-USP, em 1934, e do curso de Letras da Faculdade Nacional de Filosofia da Universidade do Rio de Janeiro, em 1939, o panorama da vida intelectual começa a se modificar. Substituindo a figura do bacharel polígrafo, dominante à época, entra em cena o especialista munido de sólida formação científica adquirida nas salas de aulas. A chegada dessa nova geração redefine os princípios e os critérios de legitimidade da atividade crítica, acentuando a distância entre diletantes e profissionais.

Rejeitando "integralmente" o "conceito impressionista que faz da crítica uma aventura da personalidade", Candido defende, em várias passagens, a adoção de uma orientação científica indispensável para o exercício da pesquisa e ensino em literatura - sem deixar de reconhecer,

6. Os marcadores "crítica impressionista" e "crítica científica" servem a variados desígnios e são acionados por ele de modo distinto em função de contextos específicos. Basta lembrar a defesa das impressōes pessoais no método crítico de Plínio Barreto, em prefácio de Papéis avulsos (1958) ou então o ensaio dedicado a Sergio Milliet, no qual Candido reivindica a retomado do ato crítico (cf. Candido, 2002d, 2000b).

7. Em ensaio de homenagem a Fidelino de Figueiredo, Antonio Soares Amora destaca a importância desse ciclo de conferências (cf. Amora, 1986, 1994). contudo, o papel desempenhado pelo gosto e apuro literários ${ }^{6}$. Comentando em rodapé quatro conferências ${ }^{7}$ promovidas pelo Departamento Municipal de Cultura e proferidas por Fidelino de Figueiredo - então responsável pela Cadeira de Literatura Portuguesa na FFCL-USP - para celebrar o centenário de nascimento do poeta português Antero de Quental, Candido de saída avalia que a proposta analítica do conferencista, de um modo geral,

[...] é mais uma crítica de erudito e historiador - crítica que situa, compara, informa, esclarece; crítica, por excelência, de períodos e movimentos literários, onde a visão panorâmica, na sua complexidade e diversidade, requer o senso histórico e a profundidade da erudição, mas que nem sempre triunfa na análise de um autor, de uma obra. Falta às vezes para esta crítica, para tanto, aquela força penetrante e como que poética de simpatia, a única, através da imaginação, que permite o contato íntimo com a criação literária (Candido, 1943a, grifos no original). 
Não obstante, diante da predominância da postura impressionista imperante - promovida em sua maior parte por "franco-atiradores" -, a atitude defendida pelo historiador português é de grande importância, pois "falta-nos o hábito e a formação necessários para nos dedicarmos ao trabalho indispensável da localização da obra no seu tempo, e à busca inteligente das circunstâncias com ela relacionadas" (Idem).

Não são exatamente a ausência de especialização e o amadorismo dos colegas de profissão que preocupam Candido, mas sim a equivocada perspectiva de análise por eles adotada ${ }^{8}$ É o que se lê, por exemplo, no rodapé dedicado à leitura da segunda série do Jornal de Crítica, publicada em 1943, de Álvaro Lins. Embora o tom elogioso predomine no artigo, Candido não deixa de registrar sua divergência em relação à postura professada pelo crítico pernambucano - o mais influente do período (cf. Bolle, 1979). Chamando a atenção para a dedicação integral de Lins ao ofício, num meio no qual "quem não reconhece em si mesmo nenhuma vocação específica se põe a fazer crítica de livros", ele comenta o empenho do crítico em averiguar "a determinação, na obra literária, daquilo que é eterno, que transcende às contingências", tornando-a "uma aventura da personalidade, um esforço para inserir na mesma ordem de que participa a essência da obra literária" (Candido, [1943] 1999, p. 17). Para Candido, porém, "por mais completa que possa ser a participação de um crítico no núcleo essencial de uma obra, é fora de dúvida que só há um meio para se chegar a eles: os seus sinais exteriores; toda aquela parte que significa neles ligação com o tempo, contingência, relatividade" (Idem, ibidem).

A mesma objeção é endereçada a Carlos Burlamarqui Kopke. Da leitura de Faces descobertas - também publicado em 1943 -, segundo livro do crítico titular do jornal paulista $A$ Noite, Candido afirma:

Quer como crítico de ficção e poesia, quer como crítico de ideias, o sr. Carlos Burlamaqui Kopke manifesta preocupações que poderiam ser chamadas de essencialistas. Quero sugerir com este vocábulo impreciso a sua tendência de procurar o sentido por assim dizer metafísico das obras. Parece-nos que ele se coloca sempre ante de um livro como que diante de um absoluto. Da Beleza, da Poesia, do Sentido. Quando fala da missão do intelectual, se refere a um certo padrão eterno de conduta (Candido, 1944d).

De acordo com Candido, o empenho analítico de Kopke é menos uma explicação do que "um esforço de comunhão" da realidade misteriosa da
8. Isso não significa que Candido não reconheça (e exorte) as profundas diferenças que separam a crítica especializada e a produzida por amadores, sempre confrontadas do ângulo das diferenças geracionais (cf. Candido, 1941a, [1943] 2002i, [1944] 2002j). 
poesia com o "drama mental" do escritor (Idem). Ao proceder dessa maneira, o autor encontrar-se-ia nas antípodas "do verdadeiro espírito crítico, ou seja: objetivo. Com efeito, o resultado da crítica deve ser uma objetivação. Ela deve poder extrair da obra analisada um julgamento tão desligado quanto possível do eu crítico, que o nosso autor pretende nunca esquecer, a fim de que este julgamento se torne um bem comum" (Idem). Por sentir-se "tanto mais à vontade para comentá-lo e tanto mais livre para apreciá-lo quanto me acho em posição bastante diversa da sua”, Candido assevera que

[...] para a compreensão e o aproveitamento humano de uma obra o critério cultural (sentido largo) me parece melhor e mais sólido do que o critério metafísico, porventura mais profundo e mais poético, porque é uma ilusão. O primeiro tende a incorporar o trabalho no patrimônio da história da cultura; o segundo, como que o limita aos prazeres de uma aventura pessoal (Idem).

Em contraposição a tal enfoque, Candido adota o conceito de funcionalidade como a diretriz geral de sua orientação analítica. No rodapé "Problema de jurisdição", datado de 11 de julho de 1943, pode-se encontrar uma definiçãao precisa da posição do autor. Respondendo a certos leitores que o haviam acusado, em "umas duas admoestaçóes escritas e umas quatro orais", de "deslizar frequentemente para fora da crítica literária e invadir canteiros do próximo", conferindo "uma notória preferência a livros que não são romances nem contos. De evitar a ficção, numa palavra [...]”, Candido esclarece que a "especificação das funções do crítico varia na razão direta da complexidade e consequente diferenciação do trabalho cultural de uma sociedade" (Candido, 1943g). Num meio marcado pela incipiente diversificação funcional, "em que não raro os indivíduos são ao mesmo tempo poetas, romancistas, críticos, escritores políticos, sociologizantes, filosofantes, é difícil dizer quais os limites precisos entre o crítico da literatura e o de ciências morais ou filosofia”, o encarregado de tal seção se vê obrigado a dar conta das solicitações que o ambiente lhe faz (Idem). Ressalvando que na revista Clima, "minha escola de crítica", "procurou-se fazer uma seleção nítida entre certos gêneros de crítica", afirma que "meus leitores nunca me viram, e provavelmente nunca me verão falar de livros de teatro, de cinema, de música, de pintura ou de economia. Quanto ao resto...” (Idem). Em vista disso, ele anuncia que o método mais adequado, até mesmo imposto por sua época, é aquele que consegue captar nas obras literárias 
[...] o que há de mais fundamente cultural, isto é, o que nelas significa o caráter comum de todas as obras de uma cultura. Assim, o crítico pode ser literário e analisar uma obra como Casa-Grande \& Senzala ou Raízes do Brasil ou História Geral das Bandeiras. Contando que considere nelas, como em Éramos seis ou no Moleque Ricardo[,] o denominador que aparenta umas às outras as diferentes manifestações de uma fase da cultura (Idem).

Para tanto, é necessário um ponto de vista, um princípio norteador:

[...] creio que não pode haver ofício mais interessante e, como desculpa vossa, mais útil do que levar para as coisas literárias certos princípios de ordem sociológica e filosófica. Daí o interesse com que, partindo de uma formação filosófica ou sociológica, é possível ao crítico embrenhar-se pela literatura, procurando interpretá-la funcionalmente, buscando nela a repercussão da época e a sublimação dos traços da cultura; selecionando, não raro, voluntariamente, os livros que mais se prestam a esse tipo de estudo. Não garanto a superioridade do método, que procuro por em prática. Mas confesso que o acho bom. E, sobretudo, útil (Idem).

Não se pode encontrar uma definição mais precisa da moldura social em que a obra literária está engastada. Condicionamento histórico-social, momento cultural e histórico, espírito de época, eis, num apanhado geral, os achados analíticos utilizados por Candido, quase sempre de maneira cambiável, para designar a preocupação com os nexos entre a produção literária e seu contexto social. É certo, contudo, que a concepção de funcionalidade por ele adotada prende-se, simultaneamente, à atuação profissional ${ }^{9}$ e às posições derivadas da militância política então exercida. Isso ao ponto dessa concepção se tornar, em certa medida, critério de aferição da qualidade literária e princípio de seleção dos autores que merecem a atenção do crítico. Uma atitude arriscada ${ }^{10}$, que tendia a transformar a obra literária em arma de combate.

No rodapé "Ficção (I)" datado de 4 de fevereiro de 1943 e dedicado à leitura de Dois mundos, livro de contos de Aurélio Buarque de Holanda, Candido indica que

Se me perguntarem qual o critério mais firme e mais imediato para se julgar uma obra de arte ou de literatura, eu direi que é o critério da sua necessidade. Necessidade, neste sentido, quer dizer a presença de uma série de razões que fazem com que a obra pareça alguma coisa que não poderia deixar de existir [...]. Este caráter
9. Apesar de não publicar nenhum ensaio científico na área da sociologia - o que somente virá a ocorrer em 1947 (quando ele se afasta da crítica literária regular) -, nesse momento Candido exercia a função de professor-assistente na Cadeira de Sociologia II e estava às voltas com a eleição de seu objeto de pesquisa de doutorado. Sob o estímulo de Roger Bastide, empreendia pequenas incursōes a municípios do interior do estado visando travar contato com práticas e manifestaçôes da cultura popular.

10. E que leva a situaçôes paradoxais: no rodapé "Vinte anos e...", dedicado a Marcel Proust, um dos autores preferidos de Candido, o elogio ao escritor francês, "na homenagem do vigésimo aniversário de sua morte", vem acompanhado da constatação de que a data "para a significação funcional de sua obra, [revela-se] quase um atestado de óbito. No amor permanente que dedicamos a Proust (veja bem o plural; se há culpa, compartilhoa com vós outros) há um pouco do amor que dedicamos às coisas mortas. Proust envelheceu. Proust passou; Proust năo tem razão de ser; Proust é uma sobrevivência de museu" (Candido, 1943d). 


\begin{abstract}
é dado à obra por um conjunto de fatores, tanto internos quanto externos, que se reúnem, afinal de contas, para a sua funcionalidade, isto é, a sua razão de ser em função de certos problemas ou, simplesmente, certas características do homem ou da sociedade de uma época. Uma obra autêntica, no sentido próprio, é sempre uma resposta: uma resposta dada por um indivíduo, de mais sensibilidade ou mais penetração do que a média, aos inúmeros problemas que ele vê ou pressente em si, nos outros ou no grupo (Candido, 1943b).
\end{abstract}

Ao caráter funcional da obra literária "vem ligar-se o seu valor próprio. Este, porém, depende em grande parte daquele. Sendo a arte, de modo geral, um fenômeno de antecipação nas esferas do conhecimento, o valor de uma obra é inseparável deste aspecto de resposta a uma incógnita - de que acima falei” (Idem). Por conseguinte,

[...] quando, portanto, uma produção do homem vem responder a este esforço de penetração, seja uma máquina que permite um domínio maior sobre a natureza, seja um poema que torna mais claro um canto qualquer da alma - podemos dizer que o seu aparecimento foi necessário, porque ela se integra funcionalmente no conjunto das atividades de uma cultura. Quando se vê que numa obra nada responde a nada; coisa alguma existe que permita sentir a sua eficiência artística - podemos dizer sem medo que esta obra é desnecessária. E tal constatação, a meu ver, é fatal para ela (Idem).

Com efeito, os 92 rodapés redigidos na Folha da Manhã assumem um registro predominantemente sociológico e político, seja em razão do quadro conceitual assumido, seja pelos pressupostos doutrinários adotados, ou, por fim, pelas preferências estéticas e autores privilegiados. Essa perspectiva fornece régua e compasso para a avaliação das obras analisadas e, nesse sentido, não me parece exagerado afirmar que, ao contrário da imagem apregoada por Candido - da sociologia como ponto de vista -, ela constitui então o fundamento central de sua orientação crítica.

Em decorrência imediata dessa posição, que atravessa de ponta a ponta o conjunto, pode-se identificar uma insistente preocupação com o papel do intelectual diante das circunstâncias históricas de período marcado pela agitação e confusão político-ideológica. Com as mudanças provocadas pela situação externa, o posicionamento do intelectual no debate sobre a vida nacional avança para primeiro plano e, com isso, a importância do empenho participativo nos rumos de sua época. 
Avaliando o lançamento de Ensaios do nosso tempo, reunião de escritos do jovem crítico Otávio de Freitas Júnior, publicado em 1944 e prefaciado por Mário de Andrade ${ }^{11}$, Candido identifica tendências conflitantes, quando não incompatíveis, nas quais se misturam a

[...] boa vontade que deseja, ao mesmo tempo, um tipo cristão de existência, a luta sem tréguas ao fascismo, uma democracia popular, uma ética individualista e essencialista. Rejeita violentamente as implicações direitistas do seu credo religioso e aceita plenamente certos aspectos populares, anti-hierárquicos da política moderna. Quer um estado de coisas em que os homens participem intensamente da existência um dos outros, todos unidos num regime de justiça social. E prega, para isso, a autorealização espiritual pela autoconsciência (Candido, 1943i)

Nesse amálgama de pontos de vista contraditórios, pode-se constatar a

[...] preocupação central do autor: a luta por um novo humanismo que substitua o anti-humanismo dos dias presentes e passados. Não me parece, contudo, que o Sr. Otávio de Freitas Junior esteja bem orientado nesse sentido. Me parece, mesmo, que não percebe o quanto a sua orientação pouco ou nada resolve. Solução de elite, solução de classe, eis o que ela é. O seu grande trunfo, com efeito, é a crença na reforma graças a uma tomada mais funda de consciência, a uma compreensão mais aguda e mais essencial dos próprios problemas por parte do homem de inteligência. $\mathrm{O}$ resto viria depois (Idem).

Girando em torno do personalismo essencialista, "característico dos diferentes espiritualismos, e que no seu caso, milagrosamente, bernanosianamente [referência ao escritor francês George Bernanos], não se acha, de modo consciente, combinado com a Reação" (Idem), o pensamento adotado pelo crítico pernambucano acaba por afastá-lo das questóes essenciais e prementes do tempo, a que Candido exclama:

Arrepio-me ao ver um moço, e dos melhores, aceitar a inteligência, não como um instrumento de vida e de reforma; de reajustamento constante do homem com as suas condiçôes de vida, que geram as condições morais - mas como a criação isenta de um enquadramento ideal, espécie de norma para uma pseudo elite intelectual, que toca harpa enquanto Roma arde e salvaguarda a pureza de um Espírito que só tem sentido humano quando se volta para o sangue e a dor dos homens. Clericalismo! Era só o que faltava! (Idem).
11. O prefácio foi republicado em Aspectos da literatura brasileira (cf. Andrade ([1945]1978). 
E arremata o artigo:

[...] não basta ser anti-fascista. Através do gidismo autofágico, da perda em si mesmo, nunca os problemas de convivência humana serão solucionados. Tomá-los como ética privada, vá lá. Há lugar para tudo, e cada intelectual tem o direito de seguir os caminhos que escolheu. Querer, porém, ver neles soluções coletivas de progresso, num livro que pretende agir sobre os outros, é erro. Erro e manivelada na roda-gigante da Reação, que gira, gira, gira, não sai do lugar, e convida os outros para as delícias do Clericalismo! Não faltava mais nada! (Idem).

Na outra ponta, investindo contra os representantes da "Reação" - sempre grafada em maiúscula-, isto é, o pensamento católico ou conservador assumido por intelectuais consagrados da geração anterior, Candido não poupa nem mesmo figuras de prestígio como Gilberto Freyre e Tristão de Athayde. Ao abordar o ensaio Mitos do nosso tempo (publicado em 1943), do intelectual católico carioca, no rodapé "Os mitos e a reação", Candido (1943e) aponta como a principal falha do livro encarar "o mito em si, buscando uma explicação de caráter filosófico, que visa julgar o seu alcance ético de acordo com um ponto de vista ontologista. Talvez fosse mais acertado fazer um estudo, que o autor não fez, do caráter funcional do mito na sociedade". Longe "de virem de crises morais internas do homem ou da falta de sentido religioso da vida" (Idem), tal como apregoava Athayde, os mitos emergem quando ocorre a ruptura entre a estrutura social e as representações coletivas correspondentes, servindo de ponto de apoio para coletividades desnorteadas. E encerra seus comentários com a seguinte frase: "Nada propondo de efetivo, [Athayde] remastiga vagos ideais. Ora, num momento em que há ideias vivas, que são soluçôes novas, o apelo reacionário ao passado é um perigo para o mundo futuro" (Idem).

\section{Por uma militância de esquerda independente}

Não é possível compreender as posições analíticas adotadas por Candido nos rodapés sob exame sem levar em conta seu envolvimento com a militância política. É nesse período que sua filiação doutrinária de esquerda aparece com maior estridência. Ele próprio, em diferentes ocasiōes, chamou a atenção para essa questão, reconhecendo a predominância de certo "sectarismo deformante" que o conduzia "para o aspecto ideológico o mais que podia; tendia, às vezes, a fazer a avaliação crítica com base na importância 
ideológica. Nunca cheguei a ser esquemático, nem fanático, mas um pouco redutor" (Candido, apud Jackson, 2002, p. 128).

De acordo com depoimento concedido à revista Praga, Candido revelou um interesse precoce pelas ideias de esquerda, ainda em Poços de Caldas (MG), onde passou a adolescência (cf. Candido, 1996a). Com o ingresso na FFCL-USP, esse interesse foi reforçado pelo contato com o professor de filosofia Jean Maügué, "simpatizante comunista e [que] aconselhava a leitura de livros de Marx, com um espírito muito aberto" e, sobretudo, pelo exemplo de Paulo Emílio Salles Gomes, preconizador de um "tipo de socialismo independente" (Idem, p. 8). Ex-membro da Juventude Comunista, encarcerado em dezembro de 1935 (na onda repressiva que se seguiu à Intentona Comunista) no presídio Paraíso - de onde fugiu no Carnaval de 1937 para o exílio na Europa -, Paulo Emílio contatou na França "grupos e pessoas de orientação marxista, mas não stanilistas nem trotskistas" (Idem, p. 8), alterando a fundo sua visão política ${ }^{12}$.

Ao retornar ao país, em fins de 1939, ingressar na FFCL-USP e conviver com Candido e os demais integrantes do que viria a ser conhecido por grupo Clima, Paulo Emilio

[...] começou a nos comunicar essas coisas, a nos dar livros reveladores, como o de Alexandre Barmine, alto funcionário que fugiu para o Ocidente e começou a revelar as iniquidades do regime socialista. Lembro da impressão que tive vendo as atas dos Processos de Moscou. Fiquei petrificado quando li as declarações dos grandes revolucionários de 1917, como Bukarin, Zinoviev, Kamenev, Radek, Piatakov e outros "confessando" que eram todos traidores a serviço das potências capitalistas! Foi uma das farsas mais trágicas e mais ignominiosas da história (Idem, p. 8).

Sob o estímulo e a orientação de Paulo Emílio, Candido integra-se no final de 1942 a um pequeno grupo de intelectuais (composto por Paulo Zingg, Eric Czaskes, Germinal da Costa Feijó e Antonio Costa Correia) que se reúne aos finais de semana para discutir temas políticos, redigir documentos e praticar alguns atos contra a ditadura. Adotando uma fórmula de ativismo marcada, de um lado, pela independência tanto em relação às posições stalinistas como trotskistas e, de outro, pela busca de um modelo de socialismo ajustado à realidade nacional - afastando-se, portanto, das diretrizes impostas pela União Soviética - o grupo adquiriu certa expressividade, juntando-se a outros na rede clandestina de luta pela redemocratização (nucleada em torno da Faculdade de Direito de São Paulo).
12. Sobre o assunto, ver Candido (1986). 
13. Não se enquadrando perfeitamente no perfil social de adeptos indicado por Rodrigues (1986) em análise sobre o PCB, Candido nāo se ligou aos partidos de esquerda tradicionais. De igual maneira, os rigores impostos pela dedicação extremada à causa não coadunavam com o perfil profissional admitido dentro da FFCL-USP (distante das questôes políticas mais candentes). Não é casual, também, que a modalidade de participação política assumida Florestan Fernandes, no interior do Partido Socialista Revolucionário (PSR), tenha se restringido à tradução e comentário de Contribuição à critica da economia politica, de Karl Marx. Sobre o assunto, ver também Ridenti (2010), Camurça (1998) e Rubim (1988).
Dessas reuniōes dominicais surge o Grupo Radical de Ação Popular (GRAP), que se ligou, em 1943, a um grupo combativo de estudantes ou jovens formados em Direito - composto em sua maioria por liberais- para formar a Frente de Resistência. A principal iniciativa dessa frente foi a publicação de quatro edições do jornal clandestino A Resistência, além do lançamento de um manifesto (redigido por Paulo Emílio) em 1945. Com o declínio da ditadura, as divergências internas afloraram e o grupo se desfaz: os liberais ingressaram na União Democrática Nacional (UDN); os socialistas fundam a União Democrática Socialista (UDS). Seguindo de perto o modelo instaurado pelo GRAP, as reuniōes do grupo ocorriam na casa de Paulo Emílio, e seu feito de maior destaque foi a redação do Manifesto da Uniāo Democrática Socialista (UDS). Dada a "dificuldade de arregimentar e coordenar as tarefas para a luta eleitoral que então se iniciava" o grupo, antes de se dissolver, coligou-se à Esquerda Democrática (ED) - que então se formara no Rio de Janeiro - e participou de seu estabelecimento em São Paulo. Em meados de 1947, a ED mudou o nome para Partido Socialista Brasileiro (cf. Candido, 1986) ${ }^{13}$.

Distanciada dos embates políticos, centrada na elucubração e intervenção intelectual, a militância assumida por Candido reivindicava uma posição independente e autônoma da disciplina e do conteúdo doutrinário exigidos pelos tradicionais partidos políticos de esquerda. Nos rodapés, suas incursões políticas privilegiam a bibliografia internacional sobre o marxismo e temas relacionados com a Revolução Russa e seus principais protagonistas. Resenhando, em 25 de fevereiro, o livro Hitler cannot conquer Russia, de Maurice Hindus - vertido para o português, numa tradução "muito má e revisão abaixo da crítica", por A Resistência Russa-, Candido adverte, de saída, o leitor: "nessa semana não farei crítica literária”, pois, há "certos livros que nos arrastam violentamente para fora da literatura, em pleno jogo das ideias vivas e dos acontecimentos" (Candido, 1943c). Ele destaca a espantosa transformação econômica que projetou o país da "extrema carência econômica, de uma agricultura primitiva, de uma indústria apenas esboçada e limitada ao aspecto manufatureiro ao segundo lugar no mundo na produção pesada e a um desenvolvimento agrícola que é o mais perfeito da terra” (Idem). A eficiência do modelo russo - reconhecida "mesmo pelos que não partilham da doutrina oficial do governo de Moscou" - parece-lhe "devida a dois fatores: compreensão clara da forma de organização econômica compatível com as condições nacionais e execução dos seus princípios dentro de um regime político que mergulhava solidamente nas tradições do país" (Idem). 
Revelando um domínio extenso da literatura sobre a história russa - sem dúvida decorrente da participação nas reuniōes da GRAP -, o artigo salienta a correspondência entre a orientação adotada na condução dos processos que culminaram na transformação indicada e características e tradições seculares do povo russo: "Longe de ser uma ruptura total com o passado, assentou a sua construção com a racionalização de alguns de seus mais sólidos princípios", não podendo "de modo algum, ser a imposição totalmente nova de um tipo de vida a um povo não preparado para recebê-la” (Idem). Assim,

O regime soviético é um fenômeno especificamente russo, que foi de encontro a condições favoráveis, propondo solução compatível com os problemas da "realidade russa”. Foi, portanto, uma revolução que se apoiou nas mais profundas tradições nacionais, e só por isso conseguiu realizar o que realizou (Idem).

A despeito da rejeição das tendências trotskistas - mas não da admiração da figura e dos escritos de Trotski -, a autobiografia do revolucionário russo, Minha vida (traduzida em 1943 por Lívio Xavier), é tratada no rodapé "Uma vida exemplar", de 4 de julho. Em tempos de domínio absoluto da doutrina stalinista, e da consequente rejeição do legado de Trotski pela maioria dos partidos políticos de esquerda, Candido, com indisfarçável satisfação, assinala a importância desse revolucionário para a concretização da Revolução Russa: se "Lenine foi o Patriarca e o Condutor, teve o seu realizador, o seu deslanchador em Leon Trotski” (Candido, 1943f). O rodapé destaca ainda a trajetória revolucionária e participação decisiva de Trotski na tomada do poder pelos bolcheviques em 1917.

A propósito do embate Trotski versus Stalin - oposição "entre a Pureza e a Eficiência” -, Candido comenta que não se deve julgar as realizações do segundo como desvios em relação ao ideário comunista, tampouco aceitálas de maneira fatalista: "[posição] que se colocam certos intelectuais de um oportunismo sem imaginação que, se escudando num soi disant motivo dialético, o que estão é, quando muito, se curvando ante não sei que desfibrado evenemencialismo, que venera e cultua o sucesso do fato consumado como a verdade suprema” (Idem). Num momento em que "sentimos no ar a ameaça, diariamente anunciada por quem sabe ver de um neofacismo de após guerra, apesar dos esforços de muitas das Nações-Unidas, torna-se mais dramático e comovente o apelo que faz uma grande vida como a de Trotski, no sentido da inteireza ideológica e da intransigência na defesa dos interesses populares" (Idem). E se indaga: 
O apelo de uma vida como a sua transcende as divisões ideológicas para se situar no campo em que se encontram todos os homens interessados em ver justiça na terra. Não é mais o trotskista Trotski quem fala. É um homem cuja vida é exemplo, cuja ação dá confiança na ação, cujo pensamento esclarece o pensamento [...]. A vida desse homem foi uma ilustração destas suas palavras. Que exemplo melhor para reinfundir confiança no homem, do fundo do caos em que estamos? (Idem).

Não se pense, porém, que as convicções políticas redundem na desconsideração pelos desafios da linguagem literária. Na leitura de Entre o chão e as estrelas (publicado em 1944), do escritor comunista Tito Batini, Candido lamenta discordar esteticamente do autor: "porque se percebe logo quanto de humanidade e justiça há na sua orientação em face do homem; como é angustiado o brado que levanta em relação à condição da massa proletária e como se orienta decididamente para a sua justa solução” (1943h). Não obstante, Batini "não tem a constituição romanesca necessária para dar aos seus ideais um cunho verdadeiro de literatura, operando a passagem da vida à arte" (Idem). Incapaz de delinear a psicologia de seus personagens - "não se tem a impressão de gente viva, mas de fantoches do autor" -, de modo a articular os acontecimentos por que passa o protagonista do romance com a "sucessão correlata de estados psicológicos que vão se organizando no sentido de uma evolução interior, isto é, da definição de uma existência" (Idem), Batini confina a vida de seus personagens ao pitoresco e ao acúmulo exterior de sentimento. Daí seu defeito ser não do

14. Em entrevista a mim concedida em janeiro de 2011, Candido confirmou que a sugestão da publicação veio da parte de José Martins. Sobre a Livraria e Editora Martins e seu proprietário, ver Silva Brito (1968) e Pontes (2001).
[...] assunto, nem da concepção de vida do autor. $\mathrm{O}$ assunto é o mais rico possível; a concepção dos homens em sociedade, a mais justa e a mais propícia para encher os pulmôes de um verdadeiro escritor. No Sr. Tito Batini o defeito vem do romancista. O romancista é que é o culpado pelo desperdício do assunto e pela inconsistência que se esvai o problema social exposto. $\mathrm{O}$ que vem provar mais uma vez que a honestidade e a boa vontade não bastam para fazer obra de arte. Esta não se nutre apenas da riqueza humana do autor, ou do seu sentido mais ou menos justo das coisas. Requer uma agudeza psicológica, um senso de participação e qualidades de composição sem as quais o resto de nada vale (Idem).

\section{Da militância combativa à brigada ligeira}

Por incentivo do amigo e futuro editor José Martins ${ }^{14}$, Candido decide reunir em livro parcela expressiva dos rodapés publicados na Folha da Manhã. 
O objetivo imediato era robustecer o currículo profissional para concorrer à vaga do concurso da Cadeira de Literatura Brasileira, que viria a ocorrer entre 23 de julho e 4 de agosto de $1945^{15}$. Publicado na coleção Mosaico ${ }^{16}$ no final do primeiro semestre desse ano, Brigada ligeira privilegiou análises de romances, o que, conforme expresso no prefácio, conferiu certa unidade ao volume. Dedicado a Alfredo Mesquita - patrocinador da revista Clima e responsável por atribuir "a seção de crítica literária" ao autor - e a Lourival Gomes Machado - que "dois anos depois" empurrou-o "para a aventura mais ampla e comprometedora do rodapé de jornal" -, o livro de estreia de Candido traduz com precisão a justaposição entre crítica literária, sociologia e política no centro de seu projeto intelectual, bem como a redefinição das posições assumidas por ele até o momento.

Organizada paralelamente à redação de $O$ método crítico de Sílvio Romero (Candido, [1945] 1988) - tese com que se candidatou ao concurso acima mencionado e a partir da qual ele começa a rever seus pressupostos intelectuais ${ }^{17}$-, a seleção dos rodapés de Brigada ligeira sinaliza, por sua vez, para uma estratégia de depuração dos excessos do engajamento então defendido por Candido. Deixando de fora artigos de circunstância, gêneros não literários (biografias, estudos históricos, historiografias literárias, traduções, palestras, coletâneas de ensaios, livros de crítica etc.), textos de cunho programático ou polêmicos e os rodapés dedicados à poesia, o autor também excluía as contingências temporais mais evidentes - não se furtando nem mesmo a retocar ou elidir trechos significativos dos artigos escolhidos ${ }^{18}$.

E com isso retornamos à questão do sectarismo crítico, abordada anteriormente. Uma avaliação detida dos rodapés dedicados à análise de poesia ${ }^{19}$ revela, talvez de maneira mais nítida do que nos escritos sobre prosa de ficção, a extensão e o limite dessa questão, permitindo uma discussão mais qualificada do problema. Diversamente das leituras dedicadas aos romances, nas quais a cobrança da participação dos intelectuais adquire uma posição mais discreta e de fundo, nos estudos de poesia Candido assume com maior ênfase a orientação política, o que acarreta, não raro, certa distorção em seus julgamentos críticos.

Se, de um lado, é verdade que o período caracteriza certa entressafra de estreias poéticas promissoras - com exceção, como veremos a seguir, de Pedra do Sono (publicado em 1942), de João Cabral de Melo Neto -, de outro, Candido não aborda o lançamento de livros importantes de poetas consagrados do modernismo ${ }^{20}$. A rosa do povo (Carlos Drummond de Andrade), As metamorfoses e Mundo enigma (Murilo Mendes), Mar absoluto (Cecília
15. O edital do concurso foi publicado no Diário de S. Paulo na data de 19 de outubro de 1944. O período de inscrição estipulado foi de 150 dias. De acordo com Candido, a tese sobre Sílvio Romero foi redigida entre $1^{\circ}$ de fevereiro e 11 de março de 1945 (cf. Diário Oficial de São Paulo,1944; Dantas, 2002a).

16. De acordo com Hallewell (1982, p. 416), em 1943, foi “iniciada a 'Coleção Mosaico', de volumes finos e de pequeno formato (17 cm de altura), de obras contemporâneas brasileiras, em sua maioria de crítica literária”.

17. Com efeito, os rodapés redigidos a partir do final do primeiro semestre de 1944 dão prova das mudanças em curso. Em "Última nota", publicado em 28 maio, Candido (1944a) cita Modern poetry and tradition de Cleanth Brooks; em "Antologias”, de 26 de março do mesmo ano, menciona Reading poems, de Wright Thomas e Stuart Gerry Brown; na revista Clima de setembro, resenha $D$. H. Lawrence and Susan, his Cow, de William York Tindall.

18. Exemplo disso é a polêmica com Oswald a respeito do julgamento da obra de Tito Batini, excluída da versão final de "Estouro e libertação" (composta da junção dos artigos "Romance e expectativa", "Antes de Marco Zero" e "Marco Zero"). Sobre a polêmica com Oswald, ver Pontes (1998).

19. Boa parte deles reunida no volume organizado por Dantas (2002b).

20. Não por acaso, a maioria desses poetas - exceto Drummond e Cassiano Ricardo- era ligada à chamada poesia espi- 
ritualista. Com a preocução de orientar o sentido geral do movimento que então surgia, a atenção de Candido recaiu preferencialmente sobre os poetas de sua geração, cuja produção despontava no cenário literário nacional. Procedimento que não deixa de ser coerente com a diretriz assumida em "Ouverture": "Assim compreendida, pois que a ela incumbe uma parte desse trabalho, a crítica - literária, artística, filosófica, científica - nos aparece como um instrumento de conhecimento e um guia nos caminhos difíceis, e a sua utilidade não pode ser negada" (Candido, [1943] 2002c, p. 28).

21. Já abordei essa questão em outro artigo (cf. Ramassote, 2009).

22. No depoimento concedido a Mário Neme, republicado em 1945 no volume Plataforma da nova geração, Candido indaga: "Quem é o grande poeta da nossa idade aqui em São Paulo: o único verdadeiro poeta, se não me engano, descontados os inéditos? Rossine Camargo Guarnieri. Qual é a característica da sua poesia? Justamente esta ausculta angustiada, de que the falo, do tempo e do homem" (Candido, [1943] 2002i, p.243).
Meireles), O sangue das horas (Cassiano Ricardo) e Cinco elegías (Vinícius de Moraes) - todos publicados entre 1943 e 1945 - são alguns exemplos disso.

Minha hipótese é de que a exclusão dos rodapés de poesia de Brigada ligeira - que perfazem apenas nove dos noventa artigos publicados - se relaciona à excessiva ênfase na defesa da poesia participante por parte do crítico, o que estava em conflito com a redefinição pela qual ele passava. Esses rodapés evidenciam que a cobrança do engajamento político dos autores estudados levou, de um lado, a uma valorização exagerada de poetas hoje esquecidos e, de outro, a uma visão bastante reticente das tendências poéticas intimistas e formalistas que culminariam logo mais na chamada geração de 1945.

Exemplar nesse sentido é o escrito "Sobre poesia", publicado em 30 de abril de 1944. Recuperando um artigo de Carlos Lacerda - "polêmico, mas perfeitamente justo em suas apreciações de ordem estética" (Candido, [1944] 2002e, p. 129) - a propósito do absenteísmo da poesia de Manuel Bandeira (que autoqualificara sua obra como menor), Candido discute as pertinência de se adotar como critério estético a oposição entre poesia menor, ou seja, marcada pelo lirismo intimista e pela notação emotiva, e poesia maior, preocupada com a meditação sobre o homem e seus problemas. $\mathrm{O}$ rodapé começa assinalando que "a poesia moderna, a partir do simbolismo, tende a ser menor", já que "a aspiração de grande parte das correntes posteriores foi se limitar aos momentos poéticos, aos momentos raros em que uma emoção agudamente sentida fosse transmitida com pureza ao leitor" (Idem, pp. 129-130). Numa palavra: "a poesia passou, em boa parte, a querer ser pura" (Idem) $)^{21}$.

Em decorrência dessa linha de raciocínio, não causa espanto a avaliação elogiosa de autores representativos da poesia participante que hoje estão completamente esquecidos. É ilustrativo, nesse sentido, o rodapé "Longitude", dedicado à leitura de $A$ voz do grande rio - publicado em 1944 - segundo livro de poesia de Rossine Camargo Guarnieri. Saudando-o como o "melhor e o mais forte dos poetas moços de São Paulo"22, Candido (1944b) lamenta que Guarnieri tenha se mantido "esquivo ante o público, guardando um silêncio interrompido após a publicação de Porto seguro, há seis anos [1938]". Por isso, "é com prazer que dou a notícia do seu último livro, A voz do grande rio" (Idem).

Esboçando uma tipologia de conotação política - ainda que reconheça o perigo de ser mal compreendido (ela poderia se prestar a "segundas interpretaçōes") -, Candido sugere que 
[...] os poetas se organizam segundo um meridiano ideal, havendo os que se colocam à sua esquerda, e à sua direita. Haveria, assim, uma esquerda e uma direita poéticas, usando os termos, não no sentido político corrente, mas relacionados a questões de técnica e de concepção da poesia. A segunda atitude caracterizaria os poetas preocupados sobretudo com a expressão do destino individual, construindo um sistema poético em que sobreleva a necessidade de expansão do eu e da obtenção de uma poesia mais ou menos pura, no sentido de bastante a si mesmo e inimiga do tema poético. A primeira atitude compreende os poetas aos quais a sua própria personalidade aparece irremediavelmente misturada com a dos outros, levando-os a coletivizar as suas emoções em oposição à primeira atividade, que procura individualizá-las ao extremo. Os poetas de direita geralmente não se ultrapassam, criando beleza dentro de condições extremamente individuais de sensibilidade. Nas coisas e nas cenas do mundo, vêm de preferência correlativos objetivos - para usar uma expressão de Eliot - das suas idiossincrasias. São, numa palavra, excessivamente teses. Os poetas de esquerda tentam transpor este individualismo, maior ou menor, abrindo a sua sensibilidade ao mundo e ao semelhante e procurando uma expressão mais total do mundo. São poetas sintéticos, se me permitem a expressão, que, partindo do seu eu (etapa em que permanecem os da primeira categoria), tomam consciência do mundo e o opõem a si mesmos, resultando, como síntese, a poesia (Idem).

Aplicada ao exame da tradição poética brasileira recente, tal classificação indica um predomínio maior de poetas à direita do meridiano adotado: "Schmidt, Manuel Bandeira, Vinicius de Moraes, Murilo Mendes - uns mais outros menos" (Idem). Por outro lado, na vertente oposta, "encontramos apenas um grande poeta, Carlos Drummond de Andrade [...]. O sr. Rossine Camargo Guarnieri também se coloca ao seu lado, embora muito lhe falte para atingir a posição verdadeiramente poética conseguida por ele e por mais alguns poucos na literatura moderna: Aragon, Spender, Day Lewis, Neruda" (Idem).

Além disso, o rodapé recusa a convicção, muito em voga à época, de que pelo fato de ser intemporal a poesia não deve "se dirigir aos problemas presentes da coletividade, pois assim se torna demasiado circunstancial" (Idem). Candido afirma que a questão reside em saber "até que ponto o tema, qualquer que ele seja, foi incorporado à sensibilidade do poeta, a ponto de se tornar poesia - isto é, estilização acentuadamente pessoal de qualquer impressão, emoção ou ideia por meio de verso" (Idem). Alinhada aos desafios de seu tempo, a poesia de $A$ voz do grande rio se nutre 
[...] do fato de todo dia, de ontem e agora. Os países que sofreram primeiro de todos os botes do fascismo são como que os heróis que aparecem a cada poema. A Abssínia, a Espanha, a China enchem as páginas com a sua dor e a sua paixão. $\mathrm{O}$ poeta sofre e canta com os seus irmãos da terra inteira, num movimento intenso de fraternidade. Parece que é este sentimento de compromisso moral, obrigação inelutável de bradar contra a iniquidade, que inflama o poeta e forma a base desse livro [...] (Idem).

A apreciação, no entanto, não deixa de assinalar ressalvas. Indicando certo desequilíbrio no livro de Guarnieri - resultado da ausência de "amadurecimento suficiente dos temas para que eles encontrem a sua forma própria" -, Candido chama a atenção para o uso recorrente de recursos como o "slogan, o dístico quase de propaganda ideológica [que] mutila dolorosamente certos poemas que, mais pensados e mais depurados, se teriam tornado obrasprimas" (Idem). Assim, "é deste equívoco que acuso o sr. Rossini Camargo Guarnieri, com tanto mais veemência quanto não se trata de um qualquer, mas de um poeta de primeira qualidade levado ao discursivismo pela sua intenção - aliás muito nobre de transformar o seu verso em arma de combate" (Idem). Seja como for, "é um livro que é necessário ler, não só porque nele se encontram poemas de vigorosa beleza, mas porque representa das poucas tentativas sérias feitas entre nós no sentido de uma poesia menos personalista e mais humana" (Idem).

O rodapé "Um poeta impuro", dedicado ao exame de Poemas - também publicado em 1944 -, de José Tavares de Almeida, segue na mesma direção. A crítica inicia com uma lembrança pessoal: a figura do poeta pernambucano discursando - "dando às palavras uma veemência de tribuno antigo" (Candido, 1944c) - no grêmio estudantil Centro XI de Agosto da Faculdade de Direito do Largo São Francisco. Na ocasião, Candido teve "a impressão exata de um último condoreiro, de um líder da Abolição cheio de imagens e bêbado com o som da própria voz. Nunca mais vi o moço de sotaque nortista. Não faz muito tempo que soube tratar-se do Sr. José Tavares de Miranda. Agora, encontro-o num livro de versos, e a lembrança daquela sessão agitada do XI de Agosto ajuda-me a compreendê-lo melhor" (Idem).

E é justamente o verbalismo do poeta ("um condor mais polido e manso") que chama a atenção de Candido. Essa característica relega "para segundo plano o elemento consciente que em geral leva o poeta a construir o poema, organizando-o e podando-lhe os brotos excessivos. O nosso poeta aceita a sua fatalidade oratória e faz bem - porque se ela o torna não raro palavroso 
e superficial, lhe dá em troca, as mais das vezes, a eloquência que leva o tema acima da banalidade" (Idem). Nesse sentido, raramente

\begin{abstract}
[...] o Sr. Tavares de Miranda usa meio tom e nunca se faz o cantor da vida corriqueira ou pequenina. Os seus temas são simbólicos ou gravemente altíssonos. Poesia para ele é exaltação antes de compreensão ou ponto de vista. Aborda o tema pelo exterior, acentuando as qualidades plásticas, as sensaçôes que lhe pode dar, a cor, o som (Idem).
\end{abstract}

\section{E sustenta:}

De minha parte, confesso que o aprecio mais por esta circunstância. Estamos num tempo em que se exagera bastante, a meu ver, as virtudes de despojamento e pureza poética. A pureza está longe de ser um ideal artístico absoluto. E mesmo de ideal humano. Nós todos sabemos o que vai de antivital, de antinatural na concepção semítico-cristã de castidade - por exemplo, que não passa de um ideal, um correspondente moral da pureza poética. Para ser fecunda, para se realizar, toda pureza deve começar por renunciar a si mesma, sob pena de ser um significado extremamente limitado e quase aberrante. E a poesia não escapa à regra. A poesia pura, despida que se nutre das migalhas do silêncio e soluça por não poder atingi-lo, é a negação mesma do esforço artístico, se quisermos ver nela a poesia.

Com efeito, Mallarmé e, sobretudo, Verlaine são, nesse momento, as bêtes noires de Candido. Ele reconhece a importância do Simbolismo francês "não só pelos valores próprios que manifestou", mas também porque tornou possível a "desbragada experimentação do cubismo poético, do surrealismo, do dadaísmo" (Candido, [1944] 2002h, p. 168). Mesmo assim, ao encerrar o rodapé sobre José Tavares, o crítico exorta:

Não é possível a arte, e, portanto, a poesia, [a] pureza que esteriliza de certo modo algumas das expressões mais vivas do homem. Como toda gente, leio Mallarmé e gosto muitíssimo dele. É dos meus poetas prediletos. Mas não quero, como muita gente, que todos os seus poemas sejam a poesia - como se pretendeu afirmar durante certo tempo. Quero os elementos humanos que a tornam comunicativa e inteligível. Quero palavras que tenham coragem de ser palavras, e não que queiram virar som puro - porque neste caso vou ao concerto. Quero poetas como o Sr. José Tavares de Miranda, impuro, cheio de demasias, porque sinto nele um calor de vida nem sempre discernível nas chinoiseries e no vocábulo puro - [coisas], aliás, mal explicadas $(1944 \mathrm{c})^{23}$.
23. Posteriormente, a concepção de Candido sobre a poesia finessecular francesa - e também sua congênere nacional - irá se modificar, tornando-se mais compreensiva (cf. Pires, 2010). 
24. Em outra ocasião, ele comenta: "[João Cabral de Melo Neto é] a mais promissora das estrelas poéticas dos últimos tempos [...]" (Candido, [1944] 2001-2002, p. 293).

25. Em "Antes do Marco zero", Oswald de Andrade detecta com precisão esse aspecto: "Aliás, o Sr. Antonio Candido é mestre nessas descobertas: a poesia brasileira começou com Rossini Camargo Guarnieri...” (Andrade, [1943] 2004, p. 68).

26. Intuição semelhante, sem contudo aprofundar o problema, encontra-se em Aguiar (2000).
Deve-se lembrar, no entanto, que Candido foi um dos primeiros a reconhecer o valor literário do estreante João Cabral de Melo Neto. O rodapé "Poesia ao norte" assinala a construção rigorosa dos poemas e a influência do surrealismo, dois dos traços que terão longa vida na fortuna crítica do autor pernambucano. Porém, o crítico não deixa de pontificar que a riqueza verbal da obra tem como contrapartida "certo empobrecimento humano": "O erro de sua poesia é que, construindo o mundo fechado de que falei, ela tende a se bastar a si mesma. Ganha uma beleza meio geométrica e se isola, por isso mesmo, do sentido de comunicação que justifica neste momento a obra de arte" (Candido, [1943] 2002f, p.140).

Como se vê, Candido não padece propriamente de insensibilidade poética - conforme o acusam seus detratores e seus adeptos o defendem -, afinal, a grandeza do poeta pernambucano foi, de imediato, assinalada ${ }^{24}$. Trata-se, antes, de uma perpectiva que decorre de uma preocupação mais geral com o afastamento dos intelectuais dos conflitos que assolavam o país e o mundo. Num momento de polarização e acirramento ideológico entre ideários de direita e de esquerda, Candido repele, com veemência, qualquer forma de absenteísmo ou alheamento dos problemas objetivos que afetavam o destino dos homens ${ }^{25}$.

Se o esforço de neutralizar os aspectos mais salientes desse sectarismo condicionou a organização do material reunido em Brigada ligeira, o perfil da crítica politicamente orientada do autor não foi totalmente relegado. Mas esse aspecto não esgota a questão. Isso porque a seleção e a reunião efetuadas por Candido são também um meio de reafirmar a trama entre áreas de pesquisa e frentes de atuação profissional na qual estava envolvido.

Apreendidos na sequência em que foram dispostos, os artigos de Brigada ligeira revelam um duplo encadeamento: de um lado, uma reflexão sobre a prosa modernista brasileira; de outro, uma análise sociológica das transformações sociais - a dinâmica de classes, os impasses dos intelectuais e o realinhamento ideológico - pelas quais o país passou no decurso das décadas de 1920, 1930 e 1940²6. Subvertendo a ordem cronológica em que os rodapés foram publicados, a entrada das análises, em minha opinião, foi concebida de modo a formar um panorama do romance modernista nesse período - bastante apropriado, aliás, tendo em vista as pretensões do crítico em relação ao concurso da Cadeira de Literatura Brasileira. Conjugando exame das características internas dos livros avaliados (traços estilísticos, construção dos personagens, composição e técnica narrativa) e comentários analíticos sobre as modificações de ordem econômica social e ideológica 
do período em curso, Candido institui uma linha de continuidade entre as obras, na qual a prosa de ficção procurava seu lugar em meio à crescente especialização do trabalho intelectual ${ }^{27}$.

Num primeiro bloco, composto pelos artigos "Estouro e libertação"28 e "Um romancista da decadência"29, Candido observa que os autores examinados não conseguem se desgarrar dos influxos estilísticos e ideológicos dos anos de 1920. Enquanto José Geraldo Vieira causa a impressão de não ter sido incomodado pela renovação promovida pelo romance de 1930, o primeiro volume do ciclo Marco Zero de Oswald de Andrade fracassa porque a técnica pontilhista utilizada não se coaduna à proposta de romance mural. Em que pese a distância que separa o cosmopolitismo do primeiro - "suprema afirmação literária” das classes dominantes, alheada dos problemas nacionais e sustentada por uma economia agrária voltada para o mercado internacional - do misto de intenção ideológica avançada e realização passadista do segundo, a técnica literária excessivamente intelectualista de ambos expressa a cosmovisão de uma burguesia que se via mergulhada no cosmopolitismo litorâneo do Encilhamento e confrontada pelos primeiros movimentos de contestação à sociedade capitalista em início de decadência ${ }^{30}$.

No centro do livro estão três artigos dedicados aos principais representantes do romance de 1930. Ao abandonar a representação pitoresca e exótica das camadas populares - mero objeto de contemplação estética - em favor de um retrato sensível de sua realidade objetiva e complexidade humana, essa geração inaugura "o romance brasileiro" ${ }^{31}$. Nesse sentido, os principais escritores dessa geração "vão viver menos obsessivamente voltados para a Europa; vão aceitar o povo, realizando e dando sentido humano ao programa estético dos rapazes de Vinte-e-Dois" (Candido, 1992c, p. 47). Essa conscientização é concomitante à aceleração das transformações econômicas e sociais operadas no meio rural e operário, que tende a integrar as grandes massas da população à vida moderna:

[...] a força do romance moderno foi ter entrevisto na massa, não assunto, mas realidade criadora. Os escritores aprenderam, no sentido pleno, com os trabalhadores de engenho, os estivadores, os plantadores de cacau, os operários de fábrica. Através dos livros, toda essa massa anônima criou, de certo modo, transfundindo o seu vigor e a sua poesia na literatura europeizada da burguesia (Idem, p. 48).

Aferrados às narrativas de cunho marcadamente social, denunciando as mazelas e as injustiças que acometiam as realidades locais e regionais,
27. No rodapé "O romance vendeu sua alma”, publicado no sexto número da revista Clima, Candido já chamava a atenção para "o abandono constante e progressivo, por parte dos artistas, do aspecto artístico da sua obra" diante da concorrência com os principais meios de comunicação de massa e da tendência a adentrar em "campo alheio e receber as mais disparatadas transfusōes. Filosofia, sociologia, política, estética - todas estas e muitas coisas mais constituem o verdadeiro recheio da boa ficção contemporânea" (Candido, 1941b).

28. O artigo examina a produção romanesca de Oswald de Andrade e foi suscitado pela publicação de $A$ Revolução melancólica em 1943.

29. Leitura de A quadragésima porta, romance de José Geraldo Vieira também publicado em 1943.

30. 1922 é ano de fundação do Partido Comunista, de realização da Semana de Arte Moderna em São Paulo e das primeiras revoltas tenentistas. Esses eventos foram registrados no estouro da prosa experimental e satírica do par Memórias sentimentais de João Miramar, de 1922, e Serafim Ponte Grande, de 1933.

31. É bastante significativa a quase completa ausência de interesse pelo romance introspectivo, apesar da publicação de obras importantes entre os anos de 1942 e 1944: Inácio (de Lúcio Cardoso), $O$ lodo das ruas e $O$ anjo de pedra (ambos de Octávio de Farias) são alguns exemplos. Em depoimento recente sobre Mário de Andrade, Candido comenta episódio - uma conversa com o escritor paulista e Fernando Sabino (de passagem por São Paulo), em que ambos defendiam o mérito literário 
de Octávio de Faria -, no qual teria dito que os romances do ciclo burguês eram "prolixos" e não questionavam a "ordem burguesa": "Eles não tiram o sono de Roberto Simonsen" (Candido, 2008, p. 50).

32. Nessa disposição sequencial é possível divisar a transição do escritor de engajamento político mais declarado para o de convicçôes mais discretas e ambíguas.

33. Sobre esse assunto, ver Nobile (2005). Deve-se lembrar que a narrativa se passa em 1935, ano da formação, crescimento e fechamento da Aliança Nacional Libertadora (ANL), e da Intentona Comunista (cf. Bueno, 2006, p. 551).

34. A esse respeito, ver o terceiro capítulo de Miceli (1979). incorporando ao gênero categorias e tipos sociais até então relegados pelos "escritores burgueses", a geração de romancistas de 1930 empreendeu a "valorização do povo", incorporando-o ao nosso "patrimônio estético e ético" (Idem). Combinando de forma equilibrada a denúncia social - as condições aviltantes dos trabalhadores da zona cacaueira da Bahia, a decadência dos engenhos da zona da mata do Nordeste e as vicissitudes das camadas médias urbanas das grandes capitais, por exemplo - com o pleno domínio dos meios de expressão literários, as obras maduras de Jorge Amado (Terras do sem fim), José Lins do Rego (Fogo morto) e Érico Veríssimo ( $O$ resto é silêncio) ${ }^{32}$ representam, ao que tudo indica, o ideal de romance almejado por Candido. Deixando de lado, nos três casos, os esquematismos e a qualidade duvidosa de parte das obras anteriores, as realizações literárias analisadas revelam a síntese feliz operada por cada autor: em Jorge Amado, a dialética entre documento e poesia; em José Lins do Rego, a tensão entre a nostalgia e o inconformismo social referente ao universo decadente de sua regiāo; em Érico Veríssimo, oscilação entre a representação da psicologia diferencial das classes sociais e o destino individual de seus membros.

No terceiro e último bloco - iniciado, significativamente, por "Estratégia” - a atenção se volta para as experiências literárias surgidas no começo de 1940. Realizando a passagem dos veteranos do romance de 1930 para os jovens estreantes do decênio seguinte, a análise do romance de estreia de Ciro dos Anjos, O amanuense Belmiro - originalmente lançado em 1937 (ano de instauração do Estado Novo) - representa um marco fronteiriço, demarcando um antes e um depois na trajetória evolutiva da prosa de ficção do período. Não constituindo um lançamento literário, Candido justifica a decisão de abordá-lo com uma referência à distinção formulada por Almeida Salles entre escritores táticos (que se valem do impulso criativo) e estrategistas (que concebem o ato criativo como um "afloramento definitivo de um largo trabalho anterior"), para anunciar que ao ler o artigo lembrou-se imediatamente de Ciro dos Anjos: "um dos maiores dentre os poucos estrategistas da literatura brasileira contemporânea" (Candido, 1992d, p. 79). Não deixando de elogiar a beleza, a elegância e o equilíbrio da prosa do escritor mineiro, nem tampouco de abordar a influência machadiana e a relação entre autobiografia e romance - aspectos destacados na recepção imediata da obra ${ }^{33}$-, a atenção de Candido retém-se no processo mais geral e nos responsáveis pela defecção por que passa a intelectualidade após a implantação do regime ditatorial de Vargas. Burocrata lírico, imerso na malhas do serviço público ${ }^{34}$, Candido vislumbra na postura de Belmiro 
[...] o destino do intelectual na sociedade, que até aqui tem movido uma conspiração geral para belmirisá-lo, para confiná-lo nas esferas em que seu pensamento, absorto nas donzelas Arabelas, nas Vilas Caraíbas do passado, na autocontemplação, não apresenta virulência alguma que possa pôr diretamente em xeque a ela, sociedade organizada. Criando-lhes condições de vida mais ou menos abafantes, explorando metodicamente os seus complexos e cacoetes, os poderosos desse mundo só o deixam em paz quando ele se expande nos campos geralmente inofensivos da literatura personalista, ou quando entra reverente no seu séquito (Idem, p. 84)

Pelo que se pode depreender do argumento de Candido, as estruturas opressivas de poder insulam os intelectuais em meros exercícios de autocontemplação e são responsáveis pela linha excessivamente personalista que passa a dominar o panorama literário do início dos anos de $1940^{35}$. Por força dessas estruturas ocorre uma radical separação entre preocupações estéticas e político-sociais, "rompendo a coexistência relativamente harmoniosa que tinha assegurado o amplo movimento do decênio de 30" (Candido, 2000b, pp. 116-117).

É nesse contexto intelectual e político que a obra de autores estreantes é lida. Singularizada pelo predomínio do romance introspectivo, desligada do meio social envolvente e pairando no jogo desinteressado da inteligência, a narrativa revelada nesse período reflete as agudas contradições sociais e a crise de consciência que marcariam o fim da civilização burguesa ${ }^{36}$. Comparada à imagem do peru hipnotizado e paralisado, a ficção autocentrada e ensimesmada dentro do "círculo magnético do próprio eu" de $A$ marca, de Fernando Sabino, padece da paralisia vital que impede a transformação do "conflito em solução dinâmica do progresso" (Candido, 1992e, p. 89). Nesse sentido,

[...] num tempo como o nosso, a linha excessivamente personalista do romance aparece, não raro, como defesa das posições já gastas da inteligência e da sociedade. Numa última palavra - e usando termos rebarbativos, pelos quais me desculpo -, se opõe ao desenvolvimento dialético da personalidade e da sociedade, procurando brecar o vir a ser por meio do prolongamento indefinido das oposiçôes do ser e do não-ser. Nisto não vai um julgamento de valor estético, mas antes histórico, em relação à literatura personalista, setor que, justamente por ser reflexo dos conflitos do nosso tempo, tem sido dos mais brilhantes da literatura deste fim de civilização burguesa (Idem, p. 92).
35. Embora não ressurja nos demais artigos, a impressão que se tem é que Candido associa o avanço da literatura introspectiva ao abafamento político causado pelo Estado Novo, o que, em certa medida, não deixa de corresponder aos fatos. No já citado estudo de Bueno, a compreensão do assunto se amplia, mostrando que o arrefecimento do romance social (ou proletário) em detrimento das tendências intimistas deveu-se tanto à incapacidade de renovação do gênero como ao realinhamento ideológico provocado pela instauração do Estado Novo. Sobre a relação entre intelectuais e o mercado de postos públicos e privados entre 1920 e 1945, ver Miceli (1979).

36. No rodapé "Esclarecendo", datado de 9 de junho de 1944 , tal questão se torna explícita: "devido ao desenvolvimento das suas contradições internas, a burguesia entrou em crise e, com ela, as suas ideologias. Nada mais natural que a crise se manifestasse no romance, um dos instrumentos mais autênticos destas [...]. Anarquizado, escapando aos quadros que o contiveram cerca de dois séculos, atirando-se à busca de novos campos, numa aventura que é das mais grandiosas da história literária, o romance é bem reflexo da crise estrutural e ideológica da burguesia [...]" (Candido, 2000-2001, p. 189). 
37. Não se deve esquecer que os três últimos rodapés redigidos por Candido enfocaram a obra poética de T. S. Eliot, outro nome de peso no cenário literário mundial. Ocorre que, de um lado, a diretriz adotada pelo livro excluiu as apreciaçóes de poesia e, de outro, o conteúdo dos artigos era "deliberadamente informativo" (cf. Candido, 2000c). Devo essa indicação a Vinicius Dantas, em conversa pessoal.

38. Sobre a recepção crítica do livro no país, ver Almeida (2000).
Do mesmo modo, $O$ agressor, de Rosário Fusco, constitui um exemplo indicativo da consciência burguesa em crise: "desvairada ante o divórcio cada vez mais pronunciado entre as suas ideologias e a sua significação social" (Candido, 1992f, p. 107). Tal como a avaliação da produção romanesca de Érico Veríssimo, o romance de estreia do escritor de Cataguases suscita comentários sobre a assimilação de correntes literárias estrangeiras. Embora Candido constate que os recursos técnicos utilizados por Veríssimo se inspiram em autores estrangeiros (especialmente os ingleses), a linguagem, os temas, os personagens e os sentimentos expressos em sua obra seriam "essencialmente brasileiros". Ao contrário do que sucede com a obra do escritor gaúcho, Candido não reconhece no romance de Fusco uma assimilação efetiva das correntes super-realistas surgidas na Europa. Daí o caráter de exercício assumido pelo livro: "tentativa de transplantar a planta estrangeira para a terra pátria”. (Idem, p. 106).

Com efeito, são poucas as análises de literatura estrangeira produzidas por Candido. Talvez o romance Monsieur Ouine, de George Bernanos, seja o principal representante desse filăo ${ }^{37}$. Além, é claro, do desafio estético que o romance impunha à recepção crítica $^{38}$, é provável que a decisão de incluir "Paixão dos valores" em Brigada ligeira tenha ocorrido em função do renome do escritor francês, então refugiado no Brasil. Católico consagrado, monarquista e antitotalitário, Bernanos residiu entre os anos de 1938 e 1945 em pequenas cidades do interior do Rio de Janeiro e de Minas Gerais. Nessa estadia, escreveu livros panfletários e artigos de jornal condenando a ascensão dos regimes nazi-fascistas e a política colaboracionista adotada por Vichy na França, e pregando um catolicismo sensível às questôes sociais.

Lançado primeiramente no Brasil - onde sua redação foi concluída -, Monsieur Ouine recebeu uma avaliação elogiosa de Candido. De acordo com o crítico, numa conjuntura marcada pela "paixão dos valores", o retrato da pequena aldeia francesa traçado por Bernanos exprime a obsolescência dos princípios valorativos que até então sustentavam os alicerces da civilização do Ocidente. No comportamento doloroso dos personagens, perdidos em uma situação de incerteza e desagregação, percebe-se o equilíbrio instável das condutas: "o indivíduo como que solicitando perigosamente as mais desencontradas possibilidades, numa verdadeira aposta, consigo próprio e com a vida, para a eleição de novos valores - aposta que pode levar à salvação ou à perdição irremissível" (Candido, 1992g, p. 113). Trata-se, pois, de "um dos romances capitais de nosso tempo, como uma grande obra que 
é necessário ler, pelo que tem de permanente no seu sentido apocalíptico e no seu admirável estilo" (Idem, p. 117).

Eis o modo como Candido encerra sua apreciação de Monsieur Ouine e, também, Brigada ligeira. Juízo significativo para se refletir tanto acerca de uma civilização em vias de reconstrução após um sangrento conflito armado mundial como sobre um país que começava a dar adeus a uma longa ditadura rumo ao futuro ainda incerto.

Em fins de janeiro de 1945, Candido se demite do cargo de crítico literário titular do jornal Folha da Manhã em solidariedade aos companheiros de redação ${ }^{39}$. Ao mesmo tempo, participa ativamente do I Congresso Brasileiro de Escritores, marco na contestação ao regime de Vargas, já em franco declínio. Oito meses depois ele voltará às páginas da grande imprensa, dessa vez assumindo a coluna "Notas de crítica" no Correio de S. Paulo, veículo no qual permanecerá pelos dois anos seguintes.

Grande parte dos rodapés escritos por ele no período permaneceu inédita. Elaborados numa etapa de indefinição profissional, em que se entrelaçam o ativismo político e as atribuições da Cadeira de Sociologia II, esses escritos instauram uma série de princípios analíticos, adesões ideológicas, predileçôes estéticas e intersecçôes disciplinares. Constituem, assim, um quadro de referências e reflexões que, em suas linhas gerais, se projeta pelo restante da produção intelectual do autor, mesmo que de modo atenuado, reformulado ou então subentendido.

\section{Referências Bibliográficas}

Aguiar, Flávio. (2000), "Brusco lampejo: digressão sobre a presença de Érico Veríssimo em Brigada Ligeira, de Antonio Candido”. In: Pesavento, Sandra Jatahy (org.). Leituras cruzadas. Porto Alegre, Editora da Universidade/UFRGS, pp. 215-223. Almeida, Teresa de. (2000), "Bernanos no Brasil: o rastro de uma permanência". In: Nitrini, Sandra (org.). Aquém e além mar: relaçôes culturais Brasil-França. São Paulo, Hucitec, pp. 115-130

Amora, Antonio Soares. (1986), "Fidelino de Figueiredo: sua obra crítica e sua ação na Universidade de São Paulo”. Tradução \& Comunicação, São Paulo, 8: 7-12, jul. (1994), "Fidelino de Figueiredo na origem dos estudos de literatura portuguesa no Brasil”. Estudos Avançados, São Paulo, 22 (8): 423-426, set.-dez.

Andrade, Mário. (1978), "Segundo momento pernambucano". In: Aspectos da literatura brasileira. 1a edição 1945. São Paulo, Editora Martins, pp. 257-262.
39. Sacchetta comenta o caso: "Certo dia o Octaviano Alves de Lima [fazendeiro ligado ao comércio de café e proprietário da Folha da Manhã Ltda. de 1931 a 1945] apareceu na redação para me comunicar um fato importante: havia vendido o jornal. Vendera para um grupo liderado por Costa Neto. O dr. Nabatino Ramos, que faria parte do escritório de Costa Neto, iria assumir a direção da empresa. Respondi ao Octaviano que as 'Folhas', também naquele momento, acabavam de perder seu secretário-geral [...]. O fato é que eu sai e comigo saíram mais de 50 companheiros. Fundamos um novo diário, o 'Jornal de S. Paulo', financiado pelo grupo da rádio Record [...]" (Sachetta, 1981, p. 325). 
Andrade, Oswald. (2004), "Antes do Marco Zero". In: Ponta de lança. $1^{\text {a }}$ edição 1943. São Paulo, Globo (Obras completas), pp. 96-103.

Bolle, Adélia Bezerra de Meneses. (1979), A obra crítica de Álvaro Lins e sua função histórica. Petrópolis, Vozes.

Bueno, Luís. (2006), Uma História do Romance de 30. São Paulo, Editora da Unicamp. Brito, Mário da Silva. (1968), Martins: 30 anos. São Paulo, Livraria Martins Editora. CAmurÇA, Marcelo A. (1998), "Intelectualidade rebelde e militância política: adesão dos Intelectuais ao Partido Comunista Brasileiro (PCB) - 1922-1960". Locus: revista de história, Juiz de Fora, 1 (4): 65-80, jan.-jun.

CAndido, Antonio. (1941a), "Apresentação". Clima, São Paulo, 1: 107-117, maio. (1941b), "O romance vendeu sua alma”. Clima, São Paulo, 6: 26-32, nov. . (1943a), "Notas de Crítica Literária - Santo Antero (I)". Folha da Manhã, São Paulo, 21/2001, p. 5. (1943ab), "Notas de Crítica Literária - Ficção (I)". Folha da Manhã, São Paulo, 04/2002, p. 5. (1943bc), "Notas de Crítica Literária - À margem". Folha da Manhã, São Paulo, 25/02, p. 5. (1943cd), "Notas de Crítica Literária - Vinte anos e...". Folha da Manhã, São Paulo, 4/2003, p.5. (1943de), "Notas de Crítica Literária - Os mitos e a reação". Folha da Manhã, São Paulo, 27/2006, p. 5. . (1943ef), "Notas de Crítica Literária - Uma vida exemplar". Folha da Manhã, São Paulo, 4/2007, p. 5. (1943fg), "Notas de Crítica Literária - Problema de jurisdição". Folha da Manhã, São Paulo, 11/2007, p. 5. . (1943gh), "Notas de Crítica Literária - Não vale a intenção". Folha da Manhãa, São Paulo, 25/2007, p. 5. (1943hi) "Notas de Crítica Literária - Inteligência e momento". Folha da Manhã, São Paulo, 12/2009, p. 5 (1944a), "Notas de Crítica Literária - Última nota”. Folha da Manhã, São Paulo, 28/2007, p. 5. (1944b), "Notas de Crítica Literária - Longitude". Folha da Manhã, São Paulo, 23/2007, p. 5. . (1944c), "Notas de Crítica Literária - Um poeta 'impuro"”. Folha da Manhã, São Paulo, 03/2009, p. 5. . (1944d), "Notas de Crítica Literária - Faces descobertas". Folha da Manhã, São Paulo, 10/2009, p. 5. . (1958), “Prefácio” In: Barreto, Plínio. Páginas avulsas. Rio de Janeiro, José Olympio. 
(1979), "Prefácio". In: Miceli, Sergio. Intelectuais e classe dirigente no Brasil (1920-1945). São Paulo, Difel, pp. IX-XIII.

. (1986), "Informe político". In: Calil, Carlos Augusto \& Machado, Maria

Teresa. Paulo Emílio: um intelectual na linha de frente. Rio de Janeiro/São Paulo,

Embrafilme/Brasiliense, pp. 55-71.

(1988), O método crítico de Sílvio Romero. $1^{\text {a }}$ edição 1945. São Paulo, Edusp. (1992a), "Prefácio da 1a Edição". In: Brigada ligeira e outros escritos.

São Paulo, Editora da Unesp, pp. 15.

. (1992b), "Entrevista". In: Brigada ligeira e outros escritos. São Paulo, Editora da Unesp, pp. 231-246.

(1992c), "Poesia, documento e história". In: Brigada ligeira e outros escritos. São Paulo, Editora da Unesp, pp. 45-60.

. (1992d), "Estratégia" In: Brigada ligeira e outros escritos. São Paulo,

Editora da Unesp, pp. 79-85.

(1992e), "Roda de peru". In: Brigada ligeira e outros escritos. São Paulo,

Editora da Unesp, pp. 87-92.

. (1992f), "Surrealismo no Brasil". In: Brigada ligeira e outros escritos.

São Paulo: Editora da Unesp, pp. 103-107. (1992g), "Paixão dos valores" In: Brigada ligeira e outros escritos. São

Paulo, Editora da Unesp, pp. 109-117.

(1993a), "Os vários mundos de um humanista". Entrevista concedida a

Gilberto Velho e Yonne Leite. Ciência Hoje, Rio de Janeiro, 91 (16): 28-41, jun. (1993b), "Érico Veríssimo de 30 a 70". In: Recortes. São Paulo, Companhia das Letras, pp. 64-73.

(1995), “Digressão sentimental sobre Oswald de Andrade”. In: Vários escritos. São Paulo, Duas cidades, pp. 67-103.

(1996a), "Antonio Candido: marxismo e militância". Entrevista concedida a José Pedro Renzi. Praga: Revista de Estudos Marxistas. São Paulo, 1: 5-21, set.-dez. (1996b), "Repúdio à doutrina do capitalismo de estado". Praga: Revista de Estudos Marxistas, São Paulo, 1: 21-24, set.-dez.

. (1997), "Prefácio". In: Bastide, Roger. Poetas do Brasil. São Paulo, Edusp, pp. 11-16.

(1999), "Sobre um crítico" [1943]. Remate dos males, Campinas, número especial sobre Antonio Candido, pp. 15-28.

. (2000a), "A Revolução de 30 e a cultura". In: A educação pela noite \& outros escritos. São Paulo, Ática, pp. 181-198. (2000b), "O ato crítico" [1981]. In: A educação pela noite e outros escritos. São Paulo, Ática, pp. 122-137. 
. (2000c), "Nota prévia". Inimigo Rumor: Revista de Poesia, Rio de Janeiro, 9:

60-61, nov.

. (2001), "Agora é com a literatura”. In: Pesavento, Sandra Jatahy et al. (org.)

Érico Veríssimo: o romance da história. São Paulo, Nova Alexandria, pp. 19-22.

. (2001-2002), "Poetas menores hoje (III)" [1944]. Literatura e Sociedade, São

Paulo, 6: 293-297. (2002a), "Prefácio à $3^{a}$ edição". In: Literatura e sociedade. São Paulo,

Publifolha, pp. 1-2.

. (2002b), "Literatura e cultura de 1900 a 1945". In: Literatura e

sociedade. São Paulo, Publifolha, pp. 101-126. (2002c), "Ouverture" [1943]. In: Textos de intervenção. São Paulo,

Duas Cidades/Editora 34, pp. 23-30. . (2002d), "Um impressionismo válido” [1958]. In: Textos de intervenção.

São Paulo, Duas Cidades/Editora 34, pp.45-50. (2002e), "Notas de crítica literária - Sobre poesia" [1944]. In: Textos

de intervenção. São Paulo, Duas Cidades/Editora 34, pp. 129-134. . (2002f), "Notas de crítica literária - Poesia ao Norte" [1943]. In:

Textos de intervenção. São Paulo, Duas Cidades/Editora 34, pp. 135-142. . (2002g), "Ordem e Progresso na poesia” [1944]. In: Textos de intervenção. São Paulo, Duas Cidades/Editora 34, pp. 143-153.

_. (2002h), "Verlaine” [1944]. In: . Textos de intervenção. São Paulo, Duas

Cidades/Editora 34, pp. 168-174.

_. (2002i), "Plataforma da nova geração" [1943]. In: Textos de intervenção.

São Paulo, Duas Cidades/Editora 34, pp. 237-250.

—. (2002j), "Notas de crítica literária - Carta a Luís Martins" [1944]. In:

Textos de intervenção. São Paulo, Duas Cidades/Editora 34, pp. 251-258.

. (2008), “Depoimento”. In: Lopez, Telê Ancona (org.) Eu sou trezentos, eu sou trezentos e cinquenta. Rio de Janeiro, Agir, pp. 37-51.

Concurso para provimento do cargo de Professor Catedrático de Literatura Brasileira.

(1944), Diário Oficial de São Paulo, 19/09, p. 20.

Coutinho, Afrânio. (1963), No hospital das letras. Rio de Janeiro, Tempo Brasileiro. Dantas, Vinícius. (2002a), Bibliografia de Antonio Candido. São Paulo, Duas Cidades/ Editora 34.

_ (org.). (2002b), Textos de intervenção. São Paulo, Duas Cidades/ Editora 34.

Dulles, John W. F. (1984), A Faculdade de Direito de São Paulo e a resistência antiVargas (1938-1945). Rio de Janeiro, Nova Fronteira.

Figueiredo, Fidelino de. (1942), Antero. São Paulo, Coleção Departamento de Cultura, v. XXVI. 
Hallewell, Laurence. (1985), O livro no Brasil: sua história. São Paulo, T. A. Queiroz/Edusp.

Hacker, Alexandre. (1998), Socialismo sociável. São Paulo, Editora da Unesp.

JaCKSOn, Luis Carlos. (2002), A tradição esquecida: Os parceiros do Rio Bonito e a sociologia de Antonio Candido. Belo Horizonte, Editora da UFMG.

(2004), "A sociologia paulista nas revistas especializadas (1940-1965)". Tempo Social, 1 (16): 263-283, jun.

Johnson, Randal. (1995), “A dinâmica do campo literário brasileiro". Revista USP, São Paulo, 26: 164-181, jun-ago.

LAfETÁ, João Luiz. (2000), 1930: a crítica e o modernismo. São Paulo, Duas Cidades/ Editora 34.

MarTins, Wilson. (1999) “A crítica modernista” In: Coutinho, Afrânio \& CouTinho, Eduardo de Faria. A literatura no Brasil. 7 ed. rev. e atual. São Paulo, Global, v. 5, pp. 591-651.

Melo e Souza, José Inácio. (2002), Paulo Emílio no Paraíso. Rio de Janeiro, Record. Miceli, Sergio. (1979), Intelectuais e classe dirigente no Brasil. São Paulo, Difel. . (2009), "Retrato do crítico jovem”. Literatura e Sociedade, São Paulo, 11: 248-253.

Nobile, Ana Paula Franco. (2005), A recepção crítica de O amanuense Belmiro, de Cyro dos Anjos (1937). São Paulo, Annablume.

Pires, Antonio Donizeti. (2010), "Antonio Candido, leitor de poesia fin-de-siècle". Itinerários, Araraquara, 30: p.115-137, jan.-jun.

Pontes, Heloisa. (1998), Destinos mistos: os críticos do grupo Clima. São Paulo, Companhia das Letras.

(2001), "Retratos do Brasil: Editores, Editoras e 'Coleçôes Brasiliana' nas Décadas de 30, 40 e 50”. In: Miceli, Sergio (org.). História das Ciências Sociais no Brasil. São Paulo, Sumaré, v. 1, pp. 419-476.

Ramassote, Rodrigo Martins. (2008), “A sociologia clandestina de Antonio Candido”. Tempo Social. São Paulo, 1 (20): 219-237, jun.

. (2009), "Antonio Candido, leitor de poesia (em torno de um artigo de Ítalo Moriconi)". Estudos de Sociologia, Araraquara, 27 (14): 445-463.

. (2010), "A formação dos desconfiados: Antonio Candido e crítica literária acadêmica (1961-1970). Cadernos de Campo, São Paulo, 19 (19): 13-34, jan.-dez.

Ridenti, Marcelo. (2010), "Artistas e intelectuais comunistas no auge da Guerra Fria”. In: _ـ Brasilidade revolucionária: um século de cultura e política. São Paulo, Editora da Unesp, pp. 57-83.

Rodrigues, Leôncio Martins. (1986), “O PCB: os dirigentes e a organização”. In: Fausto, Boris (org.). História Geral da Civilização Brasileira. O Brasil Republicano. São Paulo, Difel, tomo III, v. 3, pp. 363-443. 
Rubim, Antônio Albino Canelas. (1988), "Marxismo, cultura e intelectuais no Brasil”. In: Moraes, João Quartim (org.). História do marxismo no Brasil. Campinas, Editora da Unicamp, v. 3, pp. 305-382

SaChetta, Hermínio. (1981), “Depoimento” In: Mota, Carlos Guilherme \& Capelato, Maria Helena. História da Folha de S. Paulo: 1921-1981. São Paulo, Impres, p. 325. SÜSSEKIND, Flora. (2002), "Rodapés, tratados e ensaios: a formação da crítica brasileira moderna” In: _. Papéis colados. Rio de Janeiro, Editora da UFRJ, pp. 15-36.

\section{Resumo}

Inquietudes da crítica literária militante de Antonio Candido

Este artigo examina os rodapés de crítica literária assinados por Antonio Candido na coluna "Notas de crítica literária" do jornal Folha da Manhã, entre os anos de 1943 e 1945. Busca correlacionar a perspectiva analítica defendida pelo crítico com a militância política em pequenos agrupamentos de esquerda e as atribuições de professor-assistente da Cadeira de Sociologia II. Ao final, aborda o livro de estreia do autor, Brigada ligeira, identificando os critérios que presidiram a seleção e a reunião de seu conteúdo. Tais critérios guardam afinidade com as frentes de atuação e os princípios doutrinários assumidos por Candido no período.

Palavras-chave: Antonio Candido; Crítica de rodapé; Militância política; Brigada ligeira.

\section{Abstract}

The disquiet of Antonio Candido's activist literary criticism

This article examines the footnotes of literary criticism authored by Antonio Candido in the column 'Notes of literary criticism' in the newspaper Folha da Manhä between 1943 and 1945. It looks to correlate the analytic approach pursued by the critic with his political activism in small left-wing groups and his responsibilities as assistant professor of Sociology Chair II. Finally, the text examines the author's first book, Brigada ligeira (Light brigade), identifying the criteria involved in the selection and organization of the included essays. These criteria are closely associated with the political and professional activities and theoretical principles adopted by Candido during the period.

Keywords: Antonio Candido; Footnote critique; Political activism; Brigada ligeira.

Texto recebido e aprovado em $30 / 7 / 2011$

Rodrigo Martins Ramassote é doutorando pelo Departamento de Antropologia Social do IFCHUnicamp e técnico do Instituto do Patrimônio Histórico e Artístico Nacional (Iphan). E-mail: $<$ ramassote@hotmail.com>. 